\title{
Informal Care and Private Law: Governance or a Failure Thereof?
}

\section{Brian Sloan*}

The provision of care for elderly and disabled people is an issue of enormous public importance, particularly in the context of an ageing population. There is currently much discussion, in light of the UK Government's attempts to implement an approximation of the Dilnot Commission's recommendations on care funding, about the provision of formal care for those who require it and how it should be funded. But care recipients, and ultimately wider society, continue to rely heavily on care provided informally (i.e. in the absence of a legal duty) in the home. Many of the people providing such care suffer significant financial and health-related disadvantages as a result of their responsibilities, though in principle some are able to seek (in addition to limited support from the state) a form of 'compensation' from their care recipients via a private law claim.

This paper asks whether private law remedies for carers, such as those remedies identified and to an extent advocated in the author's recent monograph, Informal Carers and Private Law, are inevitably related to an inadequacy of state support for carers and care recipients and a failure to properly grapple with the issue of care on the part of government and society. It evaluates the alternative proposition that such remedies are normatively appropriate irrespective of the level of state provision of care or state support for informal carers.

College Lecturer and Fellow in Law, Robinson College, Cambridge. An earlier version of this article was presented at a workshop on "Care, Governance \& Law” at Kent Law School in March 2013. I am grateful to Nick Piska and Emilie Cloatre for inviting me to present at the workshop, and to the attendees for their comments. 


\author{
I. INTRODUCTION \\ II. The Social Policy Context of Informal Care in England \\ III. Justifying a Private Law Approach to Informal Care \\ IV. ConClusion
}

\title{
I. Introduction
}

The world's population is ageing. ${ }^{1}$ In Canada, for example, the number of citizens who are aged 65 or over is expected to double between 2011 and 2036, and around 25 per cent of the population is expected to be in that category by $2051 .^{2}$ In the United Kingdom, similarly, 23 per cent of the population is projected to be aged 65 or older by 2035 , while only 18 per cent will be under 16 by then. ${ }^{3}$ One of the most important questions in social policy is therefore how to allocate the burdens of funding and providing care for the increasing number of people who will require it in the decades to come. In England, there is currently much discussion about the Government's attempts to implement an approximation of the Dilnot Commission's recommendations on the Funding of Care and Support, which concern the provision of formal social care for those who require it. ${ }^{4}$ The funding question forms part of

1. See e.g. Axel Börsch-Supan, Karsten Hank \& Hendrik Jürges, "A New Comprehensive and International View on Ageing: Introducing the "Survey of Health, Ageing and Retirement in Europe"' in Peter A Kemp, Karel Van den Bosch \& Lindsey Smith, eds, Social Protection in an Ageing World (Antwerp: Intersentia, 2008) 3.

2. Employment and Social Development Canada, "Canadians in Context Aging Population" (Ottawa: HRSDC, 2014), online: Employment and Social Development Canada <http://www4.hrsdc.gc.ca/.3ndic.1t.4r@eng.jsp?iid $=33>$.

3. Office for National Statistics, Older People's Day 2011 (UK: Office for National Statistics, 2011) at 1, online: Office for National Statistics <http://www.ons.gov.uk/ons/dcp171778_235000.pdf>.

4. Commission on Funding of Care and Support, Fairer Care Funding - The Report of the Commission on Funding of Care and Support (UK: Commission on Funding of Care and Support, 2011), online: Independent Living in Scotland <http://www.ilis.co.uk/uploaded_files/ dilnott_report_the_future_of_funding_social_care_july_2011.pdf $>$. 
an overhaul of the whole system of adult social care, ${ }^{5}$ and the legislation eventually known as the Care Act $2014^{6}$ will bring about what has been described as "the biggest change in the law governing the operation of care and support in England since the National Assistance Act 1948."

The focus of this paper, however, is on the informal carer, who provides care services in the absence of any contractual or other legal duty to do so. In particular, it concerns the use of private law remedies, i.e. the outcomes of a claim by the carer against the care recipient, or more likely her estate, in order to support, compensate or reward the carer. It does not discuss particular private law remedies in detail. Much of that work was undertaken in my recent monograph, Informal Carers and Private Law, in which I evaluated property law, family property law, succession law, and unjust enrichment as potential sources of remedies for a carer from a comparative common law perspective. Rather, the purpose of this article is to consider the normative question of whether private law remedies for the carer can be justified in general, with a particular concentration on the English policy context but an awareness that private law approaches to care have been taken in several other jurisdictions including Canada.

This article begins by sketching the social policy context in which the informal carer operates in England. ${ }^{9}$ It then examines the scope for

5. See e.g. Law Commission of England \& Wales, Adult Social Care (London: Stationery Office, 2011), online: Law Commission <http:// lawcommission.justice.gov.uk/docs/lc326_adult_social_care.pdf >.

6. (UK) c 23 [Care Act]; Bill 168, Care Bill [HL], 2013-2014 sess, 2013, (3rd reading 11 March 2014). (The Bill received its first reading in the House of Commons, having passed through the House of Lords, in October 2013, which received royal assent on 14 May 2014).

7. House of Lords \& House of Commons Joint Committee on the Draft Care and Support Bill, Draft Care and Support Bill: Report (London: Stationery Office, 2013) at para 41, online: United Kingdom Parliament <http://www.publications.parliament.uk/pa/jt201213/jtselect/ jtcare/143/143.pdf>.

8. Brian Sloan, Informal Carers and Private Law (Oxford: Hart Publishing, 2013).

9. While England and Wales constitute a legal system for many purposes (including relevant private law claims), social care is a devolved matter for which the Welsh Assembly is responsible. See e.g. the Social Services and Well-being (Wales) Act 2014 (UK), anaw 4 (which received royal assent on 1 May 2014). 
a private law approach to rewarding, supporting, or compensating the informal carer. The aim is to consider whether the justification for such remedies is dependent upon an absence of proper governance of the care issue by the state. An alternative thesis, which I tentatively advance in this article, is that private law remedies could be justified independently of the quality of state provision for care or carers, and represent an aspect (albeit a small one) of appropriate governance of the issue. It is not contended, however, that it is legitimate for the state to rely solely on the availability of private law remedies in order to abdicate its governance responsibilities relating to the care conundrum. As Martha Fineman correctly argues, a societal response to the plight of the carer is not merely a matter of empathy or altruism, but of the preservation of society itself. ${ }^{10}$

\section{The Social Policy Context of Informal Care in England}

In broad contrast to health care provided under the National Health Service, many care recipients in England have to pay for formal social care on a means-tested basis. ${ }^{11}$ Social care vitally "supports people of all ages with certain physical, cognitive or age-related conditions in carrying out personal care or domestic routines." ${ }^{12}$ As things stand before the full implementation of the Care Act, those care recipients with assets worth over $£ 23,250$ must fund their own social care and receive no financial state support in order to do so. ${ }^{13}$ The relevant assets can include a home

10. Martha A Fineman, The Autonomy Myth: A Theory of Dependency (New York: New Press, 2004) [Fineman, The Autonomy Myth]. See also e.g. Jonathan Herring, Caring and the Law (Oxford: Hart Publishing, 2013) [Herring, Caring and the Law].

11. See generally Commission on Funding of Care and Support, supra note 4. C.f. the duty contained in Care Act [HL], supra note 6, s 3(1) (which would require a local authority to "exercise its functions under [the relevant Part of the Act] with a view to ensuring the integration of care and support provision with health provision and health-related provision" in certain circumstances).

12. Commission on Funding of Care and Support, ibid at 4.

13. Ibid at 11. See e.g. National Assistance (Assessment of Resources) Regulations 1992, SI 1992/2977. 
if no dependant is living in it. ${ }^{14}$ Local authorities are placed under a duty to recover payments covering residential care that they have provided in certain circumstances, ${ }^{15}$ and they also have a power to charge for non-residential services including personal care. ${ }^{16} \mathrm{~A}$ charge on the care recipient's home is one method by which a local authority can recover its costs. ${ }^{17}$

The Dilnot Commission recommended that the maximum lifetime contribution towards care expected of any one individual should be capped at $£ 35,000$, and that "the asset threshold for those in residential care beyond which no means-tested help is given should increase."18 The Government has agreed with the principles espoused by the Dilnot Commission, though clearly not the proposed figures. It has been announced that a cap of $£ 72,000$ for those of state pension age and over will be implemented in England in 2016. ${ }^{19}$ The Government has also made a commitment that, by virtue of a universal deferred payment scheme, no-one will have to sell her home during her lifetime in order to pay for care. ${ }^{20}$ While the currently anticipated cap is lower than the $£ 75,000$ cap originally proposed by the Government (with the difference being funded partly by a freeze in inheritance tax thresholds), ${ }^{21}$ either cap would still be more than double that proposed by the Dilnot Commission. The cap's narrow focus on care itself also means that it is not thought to include the cost of food or renting a room in a care

14. Commission on Funding of Care and Support, ibid at 11.

15. National Assistance Act, 1948 (UK), $11 \& 12$ Geo VI, c 29, s 22.

16. Health and Social Services and Social Security Adjudications Act 1983 (UK), c 41, Part VII. See e.g. Rv Somerset County Council, ex parte Harcombe, (1997) 96 LGR 444 (QB).

17. See e.g. Campbell v Griffin, [2001] EWCA Civ 990.

18. Commission on Funding of Care and Support, supra note 4 at 5.

19. Department of Health, Caring for our Future: Consultation on Reforming What and How People Pay for their Care and Support (UK: Department of Health, 2013) at para 22, online: GOV.UK <https://www.gov.uk/ government/consultations/caring-for-our-future-implementing-fundingreform $>$ [Department of Health, Caring for our Future].

20. Ibid at para 26.

21. "Social Care Cost Cap and Flat-Tier Pension Brought Forward", $B B C$ News (17 March 2013) online: BBC News <http://www.bbc.co.uk/news/ uk-politics-21820719>. 
home, ${ }^{22}$ and many of the details will be left to statutory instruments rather than being contained in the Care Act itself. ${ }^{23}$

Moreover, despite the Government's intention to introduce a national minimum eligibility threshold for care and support in England, the actual level of provision of social care will remain considerably subject to the discretion of local authorities, ${ }^{24}$ and again the details will be contained in secondary legislation. ${ }^{25}$ Many such local authorities are struggling to provide adequate services in the current economic climate. ${ }^{26}$ What is more, a close reading of private law cases suggests that the extent to which some care recipients will resist state involvement in their affairs should not be under-estimated, ${ }^{27}$ and many such recipients will want to stay in their own homes at all costs, notwithstanding the extent of their care needs.

It seems, therefore, that English society will continue to rely on the vital work of the informal carer, even in the context of a reformed social care system. The Government has accepted this, and given informal carers the perhaps dubious compliment that the latter "embody the spirit of the Big Society," 28 which has been described as "[a] society in which power and responsibility have shifted: one in which ... individuals and communities have more aspiration, power and capacity to take decisions and solve problems themselves, and where all of us take greater

22. Department of Health, Caring for our Future, supra note 19 at para 25.

23. Care Act, supra note 6, s 15. See Department of Health, "Closed consultation: Updating our care and support system: draft regulations and guidance" (UK: Department of Health, 2014), online: GOV.UK <https:// www.gov.uk/government/consultations/updating-our-care-and-supportsystem-draft-regulations-and-guidance>.

24. See e.g. House of Lords \& House of Commons Joint Committee on the Draft Care and Support Bill, supra note 7 at paras 189-91. Compare Care Act, supra note 6, ss 18, 19.

25. Care Act, ibid, s 13.

26. See e.g. Age UK, Care in Crisis: What's Next for Social Care? (UK: Age UK, 2012), online: Age UK <http://www.ageuk.org.uk/Documents/EN-GB/ Campaigns/care_in_crisis_2012_policy_report.pdf?dtrk=true $>$.

27. See e.g. Special Trustees for Great Ormond Street Hospital for Children v Rushin, Re Morris, decd, [2000] EWHC J0419-21.

28. Department of Health, Recognised, Valued and Supported: Next Steps for the Carers Strategy (UK: Department of Health, 2010) at 3, online: GOV.UK <http://dera.ioe.ac.uk/1972/1/dh_122106.pdf>. 
responsibility for ourselves, our communities and one another." ${ }^{29}$ The Organisation for Economic Co-operation and Development, for its part, has said that informal care provided in the home is the most important source of care from a global perspective. ${ }^{30}$

Before proceeding further, it is necessary to consider in more detail what is meant by the phrase "informal carers." Definitions are of course fraught with difficulties. ${ }^{31}$ One attempt is to say that "[a] carer spends a significant proportion of their life providing unpaid support to family or potentially friends. This could be caring for a relative, partner or friend who is ill, frail, disabled or has mental health or substance misuse problems." 32 Crucially, definitions of "informal carer" are at least intended to exclude carers for able-bodied children, ${ }^{33}$ and it is worth noting that there have been interesting discussions about the status of carers for disabled children and carers who are themselves children. ${ }^{34}$ The 2011 census data indicate that there are 5.8 million informal carers in England and Wales, ${ }^{35}$ as compared to the 5.2 million recorded by the 2001 census. ${ }^{36}$ Meanwhile, the representative organisation, Carers UK, estimates that 60 per cent of people will become a carer at some point

29. The Commission on Big Society, Powerful People, Responsible Society: The Report of the Commission on Big Society (London: ACEVO, 2011) at para 1.4, online: ACEVO <http://www.acevo.org.uk/document.doc?id=1515>.

30. Organisation for Economic Co-operation and Development, Long-term Care for Older People (Paris: OECD Publishing, 2005) at 15.

31. See e.g. Herring, Caring and the Law, supra note 10 at 13-26.

32. Department of Health, Carers at the Heart of 21st Century Families and Communities: "A Caring System on your Side. A Life of your Own" (UK: Department of Health, 2008) at 19 [Department of Health, 21st-Century Families and Communities].

33. C.f. Jonathan Herring, "Where are the Carers in Healthcare Law and Ethics?” (2007) 27:1 LS 51 at 52.

34. House of Lords \& House of Commons Joint Committee on the Draft Care and Support Bill, supra note 7 at paras 245-56.

35. Office for National Statistics, News Release, "More than 1 in 10 Providing Unpaid Care as Numbers Rise to 5.8 Million" (15 February 2013), online: Office for National Statistics <http://www.ons.gov.uk/ons/ dcp29904_300542.pdf>.

36. Office for National Statistics, "Focus on Health: 2004 Edition" (UK: Office for National Statistics, 2004) at 10, online: Office for National Statistics <http://www.ons.gov.uk/ons/rel/disability-and-healthmeasurement/focus-on-health/2004-edition/index.html>. 
in their lives. ${ }^{37}$ The opportunity costs of caring can be very high: it has been claimed that UK carers lose an average of $£ 11,000$ per year due to their caring responsibilities, ${ }^{38}$ and significant health problems often arise as a result of those same responsibilities. ${ }^{39}$ Conversely, informal care has been described as the "invisible pillar" of the welfare state, ${ }^{40}$ and the total amount of informal care provided in the UK has been valued at $£ 87$ billion per year. ${ }^{41}$

English law does make some attempt to provide state support for carers themselves, as distinct from helping the care recipients for whom they care. ${ }^{42}$ For example, the Carers (Recognition and Services) Act $1995^{43}$ granted carers the right to an assessment of their ability to provide care when a local authority is ascertaining a care recipient's need for more formal community care. The Carers and Disabled Children Act 2000 ${ }^{44}$ made the right to an assessment independent of the care recipient's assessment, and gave local authorities powers to provide services for carers, before the Carers (Equal Opportunities) Act $2004^{45}$ placed local authorities under a duty to inform carers of their rights under the previous two Acts, and

37. Carers UK, "Facts about Carers 2012" (London: Carers UK, 2012) at 2, online: Carers UK <http://www.carersuk.org/media/k2/attachments/ Facts_about_carers_Dec_2012.pdf>.

38. House of Commons Work and Pensions Committee, Valuing and Supporting Carers: Fourth Report of Session 2007-08, Volume 1 (London: Stationery Office, 2008) at para 102, online: United Kingdom Paarliament <http://www.publications.parliament.uk/pa/cm200708/ cmselect/cmworpen/485/485i.pdf>.

39. Department of Health, 21st-Century Families and Communities, supra note 32 at 100-20; The Princess Royal Trust for Carers, Always On Call, Always Concerned: A Survey of the Experiences of Older Carers (UK: Princess Royal Trust for Carers, 2011), online: Carers Trust <https://www.carers.org/ sites/default/files/always_on_call_always_concerned.pdf>.

40. Sophie Moullin, Care in a New Welfare Society: Unpaid Care, Welfare and Employment (London: Institute for Public Policy Research, 2007) at 7.

41. Lisa Buckner \& Sue Yeandle, Valuing Carers: Calculating the Value of Unpaid Care (London: Carers UK, 2007).

42. See generally Luke Clements, Carers and their Rights: The Law Relating to Carers, 5th ed (London: Carers UK, 2012) and see e.g. Herring, Caring and the Law, supra note 10 at 122-27.

43. (UK), c 12.

44. (UK), с 16

45. (UK), с 15. 
required consideration of the carer's employment, training, and housing needs as part of the assessment. Analogously with the provision of social care itself, however, Jonathan Herring has criticised the fact that such statutory provisions are "largely permissive, authorizing local authorities to provide ... services ... rather than dictating that they must." ${ }^{46}$

As well as rights relating to flexible working and non-discrimination extended to carers in the employment context, ${ }^{47}$ there is limited direct financial support available for carers in England..$^{48} \mathrm{~A}$ carer's allowance is a limited benefit payable to a person who spends at least 35 hours per week caring for someone who is herself in receipt of certain benefits related to illness or disability, ${ }^{49}$ though it has been criticised for its inadequacy. ${ }^{50}$ There is also the possibility that a care recipient could use the Direct Payments scheme to acquire the means to pay an informal carer in lieu of social care provided by the local authority, effectively transforming the care into a "care worker." ${ }^{51}$ A significant current limitation, however, is that a Direct Payment recipient is often prohibited from purchasing services from spouses, civil partners, or people living with the recipient as such, or from close relatives living in the same household. ${ }^{22}$

The Department of Health has said that the Care Act is intended, inter alia, to place carers on an equal footing with care recipients in regards to its fundamental principle that the purpose of the social care system is the well-being of the individual, ${ }^{53}$ even if the Explanatory Notes to the Act

46. Jonathan Herring, Older People in Law and Society (Oxford: Oxford University Press, 2009) at 102 [Herring, Older People].

47. See e.g. Rachel Horton, "Care-giving and Reasonable Adjustment in the UK" in Nicole Busby \& Grace James, eds, Families, Care-Giving and Paid Work: Challenging Labour Law in the 21st Century (Cheltenham: Edward Elgar, 2011) 137; Herring, Caring and the Law, supra note 10 at 247-58.

48. Herring, Caring and the Law, ibid at 120-22.

49. "Carer's Allowance", online: GOV.UK < https://www.gov.uk/carersallowances.

50. Herring, Older People, supra note 46 at 100-01.

51. Health and Social Care Act 2001 (UK), c 15, s 57. See e.g. Clare Ungerson, "Whose Empowerment and Independence? A Cross-National Perspective on 'Cash for Care' Schemes" (2004) 24:2 Ageing \& Society 189.

52. Clements, supra note 42 at para 5.40.

53. House of Lords \& House of Commons Joint Committee on the Draft Care and Support Bill, supra note 7 at paras 78-79. See Care Act, supra note 6 , s 1 . 
make clear that the principle "is not intended to be directly enforceable as an individual right." ${ }^{4} 4$ Specific reforms aimed at carers include the removal of the previous requirement that a carer either does or intends to provide regular and substantial care before his needs can be assessed by the local authority. ${ }^{55}$ As Herring points out, however, while " $\left.t \mathrm{t}\right]$ here is much to be welcomed" in the proposals embodied in the Act, "at the end of the day it will be the levels of funding which are key, rather than legislative structure." ${ }^{56}$ Given this and the general fears expressed about funding and care earlier in this section, the next section of the article considers an alternative "private law" approach to supporting informal care.

\section{Justifying a Private Law Approach to Informal Care}

The previous section of the article has demonstrated that there is currently some state support for informal carers in England, and they should benefit both directly and indirectly from a reformed social care system to an extent. But the important question for present purposes is whether we can nevertheless justify a private law approach to supporting, compensating, or rewarding the carer, perhaps as an attempt to redress the financial or health difficulties that the carer has suffered due to the responsibilities he has undertaken. For example, it could be asked whether the carer should be able to claim a share of the care recipient's estate. While my monograph did grapple with this normative question, ${ }^{57}$ I ultimately decided that because private law remedies for carers were in fact available in limited circumstances on various bases including the equitable doctrine of proprietary estoppel, ${ }^{58}$ the English Inheritance (Provision for Family

54. Care Act 2014: Explanatory Notes (London: Stationery Office, 2014) at para 57, online: Legislation.gov.uk <http://www.legislation.gov.uk/ ukpga/2014/23/pdfs/ukpgaen_20140023_en.pdf>.

55. Compare Carers (Recognition and Services) Act 1995, supra note 43, s 1(1) (b), and Care Act, supra note 6, s 10(3).

56. Herring, Caring and the Law, supra note 10 at 143.

57. See e.g. Sloan, supra note 8 at 12-20.

58. See e.g. Jennings $v$ Rice, [2002] EWCA Civ 159 and Sloan, supra note 8 at 30-90; c.f. ibid at 91-120 for an argument that a statutory solution 
and Dependants) Act $1975^{59}$ and equivalent legislation elsewhere, ${ }^{60}$ the cases in which this occurred were worthy of rationalisation and analysis irrespective of the state support question.

Given that the system of state support in England is likely to remain stretched for the foreseeable future, it may nevertheless become necessary to use private law remedies in order to adequately support and encourage informal care for elderly and disabled people where appropriate resources exist on the part of care recipients. This is particularly true in light of fears that the availability of informal care will be reduced in the years to come. ${ }^{61}$ Mika Oldham therefore pragmatically advocates a system of "successional priority" for informal carers, which would give them a prioritised right of provision from the care recipient's estate. ${ }^{62}$ It is telling that when reviewing my monograph, Herring rather humbly contrasts my own "modest" private law-oriented proposals that he considers "realisable and carefully tailored to fit within current legal approaches," ${ }^{33}$ with the "tendency for those writing in this area to insist we need nothing less than a complete change in the way we see the world and organise law." 64

An unjust enrichment lawyer might say that the carer is a "risk-taker" who has freely chosen to confer a benefit on the care recipient and should not, for that reason alone, expect payment after the event. ${ }^{65}$ Indeed, the

modelled upon the New Zealand Law Reform (Testamentary Promises) Act 1949, no 33 would be preferable to the uncertainty and controversy caused by the judicially-developed estoppel doctrine in England.

59. (UK), c 63.

60. See e.g. Graham v Murphy, [1997] 1 FLR 860 (Ch) and Sloan, supra note 8 at $136-205$.

61. See e.g. Caring Choices, The Future of Care Funding: Time for a Change (London: King's Fund, 2008) at 17, online: The King's Fund <http:// www.kingsfund.org.uk/publications/future-care-funding>.

62. Mika Oldham, "Financial Obligations within the Family - Aspects of Intergenerational Maintenance and Succession in England and France" (2001) 60:1 CLJ 128 at 173-77. See Sloan, supra note 8 at 14-20 for discussion.

63. Jonathan Herring, "Informal Carers and Private Law" (2013) 35:4 J Soc Wel \& Fam L 503 at 503 [Herring, "Informal Carers"].

64. Ibid.

65. See e.g. Andrew S Burrows, "Free Acceptance and the Law of Restitution" (1988) 104 LQR 576; Paul S Davies, "Risk in Unjust Enrichment" (2012) 20 RLR 57; Sloan, supra note 8 at 124-25. See also Jeroen 
law of unjust enrichment has not yet proved fertile ground for claims by carers (and other people in "domestic" relationships in England and Wales) ${ }^{66}$ But the Canadian courts, tending to focus on the absence of "juristic reasons" for an enrichment ${ }^{67}$ distinct from the English "unjust factor" approach, ${ }^{68}$ have been prepared to uphold claims by carers using that area of the law. ${ }^{69}$ Moreover, even if the care provided is by definition informal and not the subject of contractual remuneration in a technical sense, Fineman has argued that the choice to care "occurs within the constraints of social conditions, including history and tradition." 70 Writing from a US perspective, she fails to see why most of the costs of care should be borne by carers themselves rather than being distributed amongst the true beneficiaries of care, whether institutional or individual. If it is necessary to provide a private means of support for carers who are genuinely in need of encouragement, it also seems unjust to deny such private law remedies to those who do not require such an inducement, but do suffer disadvantages. Even in the context of entirely altruistic friendship-based relationships, John Eekelaar is content that a succession-based claim on the death of one of the parties would "fit in with the values of friendship." 71

A further question that causes difficulty, however, is whether any

Kortmann, Altruism in Private Law: Liability for Nonfeasance and Negotiorum Gestio (Oxford: Oxford University Press, 2005) at ch 11 for a general discussion of private law remedies for "good Samaritans" in English Law.

66. See e.g. Cookv Thomas, [2010] EWCA Civ 227; Walsh v Singh, [2009]

EWHC 3219 (Ch); Sloan, supra note 8 at 121-39; Sarah Nield, "Testamentary Promises: A Test Bed for Legal Frameworks of Unpaid Caregiving" (2007) 58:3 NILQ 287 at 294-98.

67. See e.g. Kerr v Baranow, 2011 SCC 10 at paras 31-32, Cromwell J.

68. Banque Financière de la Cité v Parc (Battersea) Ltd (1998), [1999] 1 AC 221 (HL) at 227, Lord Steyn; c.f. Peter Birks, Unjust Enrichment, 2d ed (Oxford: Clarendon Press, 2005).

69. See e.g. Clarkson v McCrossen, [1995] 6 WWR 28 (BCCA); c.f., e.g. Brennan v Gardy Estate, 2011 BCSC 1337. For discussion, see Sloan, supra note 8 at 129-34; Rosalyn Wells, "Testamentary Promises and Unjust Enrichment” (2007) 15 RLR 37.

70. Fineman, The Autonomy Myth, supra note 10 at 41.

71. John Eekelaar, Family Law and Personal Life (Oxford, Oxford University Press, 2007) at 48. 
justification for a private law approach depends on the failure of the state to provide adequate support for care and carers. It could be argued that in a perfect society, the state would provide adequate support such that any justification for private law remedies that previously existed immediately falls away. It could also be said that, given the anxiety about the amount that individuals should have to pay towards the cost of formal care, it would be very difficult to justify imposing additional liability in respect of informal care on care recipients.

But it is not clear that things are really as simple as that. Many scholars are quite content to say that there should be some sort of redistribution of property following the end of a marriage or civil partnership, ${ }^{72}$ in spite of the potential availability of state benefits for the parties to the relationship. ${ }^{73}$ Indeed, one of Lady Hale's concerns about the greater enforceability of pre-nuptial agreements in England, expressed in her dissenting speech in Radmacher $v$ Granatino,${ }^{74}$ was that an economically stronger party could use such an agreement to "cast the burden of supporting her husband onto the state" rather than undertaking the burden herself. ${ }^{75}$ When evaluating the English Law Commission's proposals for an equivalent redistributive scheme for unmarried cohabitants, ${ }^{76}$ Simone Wong has argued that there is "no logical reason to limit access to the law to only couple-based relationships," 77 even if she emphasised the distinctive

72. See e.g. Jonathan Herring, Family Law, Gth ed (Harlow: Pearson, 2013) at 212-19.

73. For an argument that financial support should be a matter of public liability rather than private law, see Kevin J Gray, Reallocation of Property on Divorce (Abingdon, UK: Professional Books, 1977) at 302-34. See also Lucinda Ferguson, "Family, Social Inequalities, and the Persuasive Force of Interpersonal Obligation” (2008) 22:1 IJLPF 61 (for a useful discussion of the appropriate respective roles of public and private law in this context from a Canadian perspective).

74. [2010] UKSC 42.

75. Ibid at para 190.

76. Law Commission of England and Wales, Cohabitation: The Financial Consequences of Relationship Breakdown (UK: Law Commision, 2007), online: GOV.UK <https://www.gov.uk/government/uploads/system/ uploads/attachment_data/file/228881/7182.pdf>.

77. Simone Wong, "Caring and Sharing: Interdependence as a Basis for Property Redistribution" in Anne Bottomley \& Simone Wong, eds, Changing Contours of Domestic Life, Family and Law: Caring and Sharing 
nature of the commitment in such conjugal couple-based relationships in later work, ${ }^{78}$ and even though a lot of informal care self-evidently takes place within couple-based relationships.

Moreover, testamentary freedom is already limited in English law through its allowing a wide range of individuals to claim discretionary provision out of a deceased person's estate under the Inheritance (Provision for Family and Dependants) Act $1975,,^{79}$ some of whom are carers, ${ }^{80}$ and it might legitimately be asked why a carer for that person should not be specifically recognised as a potential family provision claimant in his own right, particularly where a such a person has a need for future maintenance comparable to that of other possible claimants as a result of his caring. The specific inclusion of caring relationships in such legislation is not a fanciful suggestion, but already occurs in several parts of Australia, for example. ${ }^{81}$ Analogously with the widely accepted view on divorcebased claims, under the current law of family provision on death, English courts are generally reluctant to attach a great deal of significance to the availability of state support for an applicant when evaluating his claim. ${ }^{82}$

(Oxford: Hart Publishing, 2009) 49 at 54. C.f. the Commission's own conclusion in an earlier project that "[i]t is not possible ... to devise a statutory scheme for the ascertainment and quantification of beneficial interests in the shared home which can operate fairly and evenly across the diversity of domestic circumstances which are now to be encountered," see Law Commission of England and Wales, Sharing Homes: A Discussion Paper (UK: Law Commission, 2002) at 85, online: Law Commission <http://lawcommission.justice.gov.uk/docs/Sharing_Homes_Discussion_ Paper.pdf $>$, which led it to exclude non-conjugal caring relationships from its cohabitation project, see Law Commission of England and Wales, Cohabitation: The Financial Consequences of Relationship Breakdown: A Consultation Paper (UK: Law Commision, 2006) at para 9.136, online: Law Commission <http://lawcommission.justice.gov.uk/docs/cp179_ Cohabitation_Consultation.pdf>. See Sloan, supra note 8 at 206-08 for discussion.

78. Simone Wong, "Shared Commitment, Interdependency and Property Relations: A Socio-legal Project for Cohabitation” (2012) 24:1 CFLQ 60 at 74-75.

79. Supra note 59.

80. See e.g. Sloan, supra note 8 at 136-205.

81. See generally ibid; see also Adult Interdependent Relationships Act 2002, SA c A-4.5 and Wills and Succession Act 2010, SA c W-12.2, ss 72(b)(ii), 88.

82. See e.g. Re E, Ev E, [1966] 2 All ER 44 (Ch); Re Collins, decd, [1990] 
Perhaps it is possible to go as far as to say that private property redistribution is more readily justifiable in the case of a genuine caring relationship rather than a marriage or couple-based relationship per se, since a true caring relationship confers a vital benefit, by definition. In other words, a caring relationship is not necessarily a status-based relationship like marriage or civil partnership, in relation to which the English courts are to some extent content merely to assume that there is a justification for a redistribution of property rights when a relationship breaks down by virtue of a "partnership" model, ${ }^{83}$ but arguably provides more benefits to society per se than some of those status-based relationships. Recognition of this notion would take us closer to the focus on the "carer-dependant" paradigm that Fineman (at least at one time) considered vital for family law ${ }^{84}$ and, in Maxine Eichner's words, change "the basis of entitlement ... to desert."

Public opinion may jeopardise such principled thinking. There is at least some evidence that a significant portion of the population is uncomfortable with the idea of linking care and private rewards,${ }^{86}$ and care must be taken that people are not allowed to fall unknowingly into relationships generating rights and obligations without good reason. ${ }^{87}$ There is, moreover, a converse risk that the recognition of

Fam 56 at 61-62, Hollings J; Ilott v Mitson, [2011] EWCA Civ 346 at para 75 , Arden LJ.

83. See in particular Miller v Miller; McFarlane v McFarlane, [2006] UKHL 24, concerning the use of the courts' powers to redistribute property under the Matrimonial Causes Act 1973 (UK), c18, Part II; and see e.g. Lisa Glennon, "Obligations Between Adult Partners: Moving from Form to Function?” (2008) 22:1 IJLPF 22 at 40.

84. See Shazia Choudhury \& Jonathan Herring, European Human Rights and Family Law (Oxford: Hart Publishing, 2010) at 426, and Herring, Caring and the Law, supra note 10 at 187-233 for discussion. C.f. Martha A Fineman, "The Vulnerable Subject: Anchoring Equality in the Human Condition" (2008) 20:1 Yale JL \& Feminism 1.

85. Maxine Eichner, "Dependency and the Liberal Polity: on Martha Fineman's The Autonomy Myth" (2005) 93:4 Cal L Rev 1285 at 1291.

86. See e.g. Karen Rowlingson, "Attitudes to Inheritance: Focus Group Report" (Bath: University of Bath, 2004), but c.f., e.g. Deirdre G Drake \& Jeanette A Lawrence, "Equality and Distributions of Inheritance in Families" (2000) 13:3 Social Justice Research 271.

87. See e.g. Nicola Peart, "De Facto Relationships (or Maybe Not) in New 
caring relationships facilitating property redistribution, inter alia, could be manipulated to undermine equality-oriented legislation aimed at conjugal same-sex couples. ${ }^{88}$ It is nevertheless significant that although Fineman herself advocates for greater state support of the carer, she also accepts that care recipients "owe an individual debt to their individual caretakers," which exists alongside a broader societal debt owed to those carers. ${ }^{89}$

It is not my intention to argue here that private law should be the predominant means of support for carers, that a claim should be available in every situation, or that a carer should automatically be paid out of the care recipient's resources as though he had been providing formal social care for her. Indeed, in many cases a claim will be impossible simply because the care recipient has lived or died with insufficient assets, particularly in light of the formal care costs considered above. ${ }^{90}$ Moreover, we should not seek to encourage the state to regard private law as the major mode of governance in relation to care, and Susan Boyd and Claire Young rightly express concern from a Canadian perspective that the recognition of a variety of relationships can cause governments to "offload responsibility onto those private relationships, resulting in more expectations being made of those relationships in terms of taking care of 'their own."'91

It is also legitimate to quibble about important details of any private law claim by a carer, as I did in my monograph, and specifically about questions such as: should the claim be dependent on a promise made by

Zealand" (2008) IFL 113.

88. See e.g. Lisa Glennon, "Displacing the 'Conjugal Family' in Legal Policy - A Progressive Move?” (2005) 17:2 CFLQ 141 (which includes analysis of Canadian developments such as Law Commission of Canada, Beyond Conjugality: Recognizing and Supporting Close Personal Adult Relationships (2001) in this regard); Sloan, supra note 8 at 206-16. C.f. Herring, "Informal Carers", supra note 63 at 505.

89. Fineman, The Autonomy Myth, supra note 10 at 48.

90. See e.g. Lorna Fox O'Mahony, Home Equity and Ageing Owners: Between Risk and Regulation (Oxford: Hart Publishing, 2012) at 32-37.

91. Susan B Boyd \& Claire FL Young, “From Same-Sex to No Sex'?: Trends Towards Recognition of (Same-Sex) Relationships in Canada” (2003) 1:3 Seattle Journal for Social Justice 757 at 784 . 
the care recipient to the carer?; ${ }^{92}$ what should be the basis for relief?; ${ }^{33}$ how should the "carer" be precisely defined?; should claims be actively restricted to the time after the care recipient has died?; ${ }^{4}$ or how should the carer's claim be weighed against those of non-caring but dependent family members? ${ }^{25}$ This article simply suggests that a normative justification for supporting care using private law can be found, and that it does not necessarily depend fully on inadequate state support for care in the true sense.

\section{Conclusion}

I hope I have provided some food for thought in this article. Of course, whatever the lofty aims of the Care Act, it seems unlikely that we will ever live in that perfect society where the state will provide fully adequate support for carers and care recipients. In the imperfect context, private law could well come increasingly to the fore, and the question posed in this article may never really have to be posed by policymakers in an undiluted form. While private law should never be used to allow the state to abdicate its responsibility to ensure that care is supported, a normative justification for a private law approach to the issue can nevertheless be found. As a closing question, readers may wish to consider why society might be more comfortable about private redistribution of property in respect of some socially useful relationships than others.

92. See e.g. Sloan, supra note 8 at 21-23, 239-43.

93. See e.g. ibid at 24-25, 244-45.

94. Compare ibid at 136-205, 206-16.

95. See e.g. ibid at 206-16. 